\title{
SURVIVING STATE-LED DISASTER: THE LEGACIES OF HILLSBOROUGH
}

\author{
Sally Day and Elizabeth Stanley
}

\begin{abstract}
This article explores the trajectories of survival in the aftermath of state-led disaster. In particular, it considers how survivors have experienced and understood their survival from the 1989 Hillsborough disaster and its subsequent injustices. Drawing upon interviews and conversations with those who experienced the disaster, as well as with key professional informants, it critically examines the factors that assist or inhibit survival attempts. The article shows that survival significantly depends upon wider official and social responses to survivors. Survival is a continual process, and responses towards survivors can support quality of life but also cause re-victimization and retraumatization.
\end{abstract}

Keywords: survival; state crime; Hillsborough; disaster; revictimization

\section{Introduction}

Ninety-seven ${ }^{1}$ men, women and children were unlawfully killed at the Hillsborough football stadium on 15 April 1989. The disaster ${ }^{2}$ was both foreseeable and preventable. Despite the stadium's well-documented history of serious safety problems, South Yorkshire Police (SYP) officers took unprecedented decisions that led to a life-threatening crush in two spectator pens (see Hillsborough Independent Panel [HIP] 2012; Scraton 2016). Viewing the ensuing devastation, Match Commander chief superintendent Duckenfield instructed officers to attend to "crowd disorder" and a "pitch invasion." During this fatally inappropriate response, officers prevented the entry of emergency services to the ground and refused desperate pleas from crushed fans to open the gates. The pens filled to three times their capacity before a safety barrier in pen three collapsed. A rescue response was led by courageous survivors, and other fans including off-duty emergency workers. Yet, so many people were killed in horrific circumstances at an annual sporting event, while hundreds more were injured and thousands traumatized (HIP 2012).

While the behaviour of Liverpool Football Club fans attending the match played no part in causing or contributing to the disaster (HIP 2012; Press Association 2016), the nature of official misinformation, misrepresentations and

Te Herenga Waka-Victoria University of Wellington 
falsified evidence meant they were long regarded as responsible (Scraton 1999, 2016). This began with Duckenfield's account to the Football Association (FA) that fans caused the crush. The FA relayed this lie to journalists and it was quickly broadcast around the world. From this point, those primarily responsible manipulated knowledge of the disaster and its aftermath. One infamous example was the "reporting" by The Sun, that ran a piece (headlined "THE TRUTH") that blamed Liverpool fans and printed multiple non-truths (Arnold 1989). These fictions were repeated across media, political debates, and even academic texts (HIP 2012). As Martin Thompson, who lost his younger brother Stuart at Hillsborough, ${ }^{3}$ observed: "the media at the time had taken the side of the police and we - the fans and families - were treated with disdain" (Thompson 2017: para. 6).

Over the next decade, authorities relied on organized untruths (such as largescale amendments to police statements) to minimize their failures and avoid culpability. This flowed through to multiple inquiries and investigations, including: criminal and disciplinary investigations by the West Midlands Police Force, Sheffield Council and the Health and Safety Executive (1989); LJ Taylor's Interim and Final Reports from the original inquest (1989-91); civil litigation; judicial reviews (1989 and 1993); a judicial scrutiny of new evidence (1997-8); and the private prosecution of the two most senior police officers in command on the day (1999-2000). Throughout, bereaved families, survivors and advocates railed against the lack of transparency, adversarial approaches and an unrelenting accusatorial tone towards fans (Scraton 2016). Survivors were blamed, almost entirely, for deaths and injuries that were not of their making.

It took almost three decades for the factual causes of the disaster and those authorities responsible to be officially recognized through the 2012 Hillsborough Independent Panel (HIP) Report. This was followed by the quashing of "accidental death" verdicts and the 2016 Inquest Verdict (IV) that, among other things, recorded that those who died were unlawfully killed, and that fans' behaviour had not caused or contributed to the disaster. With these truths officially recorded, the Hillsborough case moved to the courts. Here, former chief superintendent Duckenfield was acquitted on charges of gross negligence and manslaughter in 2019 while, in 2021, a trial against two senior police officers and a former solicitor for South Yorkshire police (on charges of perverting the course of justice, by altering police statements) was stopped on a technicality (Conn 2021). ${ }^{4}$ After years of legal action, there has been only one conviction for Hillsborough - the Secretary of Sheffield Wednesday football club was fined $£ 6,500$ for a health and safety offence.

This article does not further address matters of accountability. Instead, it considers the broader issue of survival. In particular, it outlines the factors that inhibit survival chances for those who experience state-led disaster and it reflects on the personal, community and state-institutional factors that can enhance survival 
trajectories. In short, it reflects on how survival is articulated, experienced and managed following state crimes.

\section{The Research}

Taking a critical social research approach - with an ethos of registering oftenmarginalized voices as a means to "speak truth to power" and unsettle establishment narratives - the article is based on in-depth interviews with survivors, ${ }^{5}$ bereaved family members and advocates, undertaken by the lead author in $2016{ }^{6}$ In total, nine interviewees are featured in this article: Nick Braley, Peter Carney, Paul Dunderdale, Steve Kelly, Tim Knowles, Tony O’Keefe, Adrian Tempany, Dan Kay and Sheila Coleman. Of these, five survived the crush (and one is also a bereaved family member), one became a rescuer on the day, one is a bereaved family member and two are ardent long-term campaigners. The authors have also engaged with other individuals, such as Phil Scraton who has extensive professional involvement in the area, having written the book on Hillsborough, and authored the HIP Report (Scraton 2016; HIP 2012). ${ }^{7}$

Ethics approval was granted from Victoria University of Wellington. However, ethical considerations progressed through the research process, to safeguard the welfare of participants and those victimized more broadly. Starting with approaches to professionals, a snowballing method was used to ensure the research only engaged with those people who expressed interest and volunteered to take part. Once interviews were complete, and transcripts reviewed and approved by participants who requested them, the data was thematically analysed and dominant themes drawn out to reveal collective interpretations of experience (Grbich 2013). In this case, themes were coded into broader categories or patterns of meaning. The core findings from these analyses are presented below.

\section{Victimization, Survival and Disaster}

Most representations of victims are constructed according to a prior interpretation of what is defined as crime as well as the supposed characteristics of those who will suffer those crimes (Walklate 2007). Assigning victim status often involves the socially constructed "ideal victim" as a reference point (Christie 1986). "Deserving" victims are expected to be upstanding moral citizens, passive, helpless, powerless and preferably victims of conventional crime (Christie 1986). These "legitimate" victims may receive compassion and empathy. Conversely, those who do not conform to this polarizing stereotype can be regarded as somehow to blame for, or deserving of, their victimization. Their victimization can subsequently be minimized, ignored and sometimes even celebrated. 
Such distortions of victimhood also create misrepresentations of survival. Within much mainstream literature, the term survivor is presented as a desirable state, associated with the transcendence from a traumatized victim to an empowered survivor. However, survival trajectories are often non-linear, and involve complex journeys. Feminist writers such as Liz Kelly (1988) have recognized that survival is on a continuum. That is, survival does not exist on a linear progression, rather there are diverse experiences of survival over time (Kelly 1988). Multiple survival trajectories ripple out across family, kin, community, organizations and also across generations - there are many types of survivors, even from the same event.

Conceptualizing survival in this way gives victims/survivors the power to identify and articulate the multiple dimensions of survival (Kelly 1998). For example, it gives people the freedom to acknowledge shifting states, such as being in a more traumatized state at one point to moving to a less traumatized state and vice versa, depending on changing factors. The survival continuum also promotes a critical recognition of victimization, including how victims are responded to, why victims are treated in certain ways, or what victims need in order to survive (Kelly 1998; Profitt 1996). It also allows us to understand how notions of who and what a real victim or survivor is depend upon the discourses and activities of key definers. In a disaster context, state actors play a vital role in supporting or undermining personal survival efforts.

\section{Official Responses to Disaster}

Disasters are rarely natural, especially as the decisions made by officials pre- and post-disaster can cause extensive and unnecessary damage. Official responses to disasters are rooted in pre-existing economic, social and political structures (Green 2005). All states have the power to dictate pre- and post-disaster conditions, and their top-down approaches can exacerbate social inequalities and dominant power structures (Green 2005; Spring 2011; Urbatsch 2016).

Following disasters, governments are charged with a duty of care and are expected to minimize damage and aid recovery (Verchick 2012). However, disastrous outcomes often result from government omissions or inaction (Faust and Kauzlarich 2008; Green 2005, 2008). Official institutions regularly fail to enforce safety regulations, remain apathetic towards safety and emergency procedures, and frequently prioritize organizational goals or economic conditions that make disasters more likely (Tombs and Whyte 2007). Many disasters emerge from the "wilful avoidance" of safety codes, regulations or other measures to avoid preidentified harms (Green 2005: 538; Faust and Kauzlarich 2008).

At the same time, government responses to disasters are "almost deliberately, ineffective" for those who are placed in situations of vulnerability or marginalization (Hooks and Miller 2006: 25), who are over-represented in experiencing disaster 
(Verchick 2012: 29; Green 2008; Spring 2011). Under these circumstances, victims have to survive the disaster as well as the way the state responds to them. The harms generated from state actions or omissions during times of disaster create personal, economic, social and political damage, all of which detrimentally affect survival (Faust and Kauzlarich 2008; Green 2005, 2008; Olson 2000; Verchick 2012).

Research shows how official responses (that can involve the state's denigration of victims/survivors, deflection of allegations, control of investigations, a reliance on flawed evidence, legal manipulation and silencing) are often revictimizing and retraumatizing (Stanley 2015). For example, engagement with formal processes frequently exposes victim/survivors "to invasive personal scrutiny" (Lundy 2016: 13). Attending adversarial court proceedings, especially when the outcomes are viewed as unjust, can "activate delayed onset PTSD" (Smith and Heke 2010: 13), increase existing PTSD symptoms and shatter victim/survivors' illusions of justice, further undermining mental health and provoking traumatic stress (Herman 2005; Orth 2002). Psychological harms are further exacerbated when formal processes are dragged out over long periods of time (Lundy and Mahoney 2018).

Part of the problem is that most official responses fail to holistically address harms or respond to victim/survivors' requests; they are rarely survivor-led (Daly 2017; Herman 2003). Formal proceedings such as court and inquest hearings do not often fulfil "justice interests" (Daly 2017: 111, original emphasis; Orth 2002). Victims/survivors want multiple measures, including: official acknowledgement of wrong-doing; apologies; consultation in the development of formal processes and the ability to participate in them; memorial projects; well-being supports such as counselling and survivor support groups; intergenerational supports; financial compensation; restorative justice; accountability of those responsible; and socio-cultural and institutional changes to prevent future harms (Daly 2017; Herman 2005; Lundy 2016; Lundy and Mahoney 2018; Orth 2002; Stanley 2015). Conventional justice responses bypass most of these varied and innovative response mechanisms and subsequently fail to attend to victims/survivors' needs. Under these conditions, the ability of survivors to survive well is severely compromised.

\section{The State-Protective Narrative of Resiliency}

Such difficulties are further exacerbated by the dominance of resiliency as a central state response to personal experiences of harm and trauma. Resiliency is seen as the ability of individuals and/or communities to bounce back to a pre-disaster state in the fastest possible time, often with minimal or no help (Manyena et al. 2011; McGreavy 2015). Those who are successfully resilient can withstand negative effects and recover in a timely fashion, compared to those who are not coping and so are not being resilient (Shaw 2012). It is thought that, by being resilient, whatever that entails, individuals will effectively survive (Manyena et al. 2011). 
While favoured by Western government agencies, the emphasis on resiliency is deeply challenging to those who suffer disasters. Resiliency emphasizes self-help and self-responsibility, which detracts from the structural, socio-economic or political conditions that cause disasters, and that deeply affect personal well-being in their wake (Alatartseva and Barysheva 2015). Under a resiliency remit, governing institutions expect that individuals will use their initiative and achieve a positive quality of life, regardless of circumstances. This notion of resiliency propounds "individual remedies for social maladies" (Prilleltensky and Prilleltensky 2005: 91) yet, in reality, individuals and communities will rarely enjoy a smooth survival trajectory or return to a pre-disaster state (McGreavy 2015).

It is perhaps no surprise that this emphasis on resiliency has emerged at a time of advanced neo-liberalism. Disaster victims are made responsible for regaining control and rejecting vulnerability after disasters (Leichenko et al. 2015). They must move on from traumatic events to a state of functioning, and economically productive, survival. The idea of resiliency operates, then, as a regulation mechanism by encouraging conformity to officially sanctioned responses to disaster (Prilleltensky 2008; Spring 2011). Moreover, under resiliency notions, state institutions are further absolved of responsibility in dealing with the disaster or providing support (Manyena et al. 2011; Shaw 2012). The focus on an individual's capability to live up to the expectation of being resilient decontextualizes disaster and prevents any critical social transformation of the structures and processes that actually lead to victimization (Shaw 2012). In many ways, these dominant narratives are inherently protective of state (and other powerful) interests.

\section{The Struggle to Survive Hillsborough}

In many respects, state actions following Hillsborough have exemplified the most detrimental and revictimizing approaches to survivors (Scraton 1999, 2013). State protectionism has been engaged at every level, and created numerous long-term difficulties for survivors. ${ }^{8}$ Here, we detail five key concerns: the overarching lack of recognition towards survivors, being blamed, being revictimized, their limited supports and expectations from others to "get over it." They have commonly been expected to be resilient, quiet and uncomplaining.

First, Hillsborough survivors are rarely identified as victims or survivors. As Tim explained: "we've generally been described as the 'fans', this anonymous mob . . . but, no, I very nearly died in an incident, which killed 96 people so therefore I am a survivor." Without recognition, survivors have not been treated or responded to by official agencies as victims. Their perspectives and experiences have rarely been taken into account (see also Bracken 2009). 
Second, as noted above, the societal lack of recognition of survivors and their trauma has been fuelled by state-led victim blaming. Wide-reaching smears from politicians, journalists and legal representatives "demonized" and "dehumanized" survivors (Tim) and exacerbated their trauma (Sampson 2016). One survivor described these blame-focused representations as "torturous" (Paul) particularly as, in many respects, the fans had been "the heroes, they were jumping back in the pens, they were trying their very very best to pull things down with their bare hands ... we should be honouring them" (Steve).

This victim-blaming led to detrimental outcomes including survivor PTSD and guilt. One survivor, Tony Cottier, articulated his ongoing struggles: "I was 18 at Hillsborough, and have felt nothing but guilt since, for having been able to come home that night" (LFC History 2019: para. 3). Adrian explained: "it [trauma] very nearly derailed my life at a number of junctures." Survivors have struggled with being unable to reconcile their experiences with official versions - the dissonance has triggered panic attacks, nightmares and breakdowns. Some survivors have self-medicated, self-harmed or taken their own lives (see Newburn 1993). Many acknowledged the fate of others who will always be at risk of not surviving.

Third, survivors have been deeply affected by the failings of inquests, scrutiny, civil litigation or private prosecutions to protect them, or to provide truth or justice. People almost had no choice but to "put their faith in the system" (Sheila), but they have been revictimized by state-protective processes and decisions that prioritized legal technicalities over "just" responses and even "put the fans back on trial" (Nick). Survivors struggled in "challenging the verdicts and opinions which contradict [their] living experiences" (Peter). Tim explained, "the fact that it was the establishment defines everything ... there are no depths that they will not sink to in order to get out of being blamed ... this is what we're up against." Interviewees saw an unavoidable chain-reaction of negative consequences from these official proceedings, including premature death. Tony, for example, observed that "fighting against the establishment" eventually killed ardent campaigner and bereaved mother Anne Williams ${ }^{9}$ (see also Williams and Kay 2013).

Fourth, given their non-recognition as victims, and their blameworthy identification, survivors have enjoyed little professional support, help or counselling. Sheila observed that "the help for survivors has always been woefully inadequate." In the immediate aftermath, authorities established the Hillsborough Centre in Anfield Road, Liverpool. The centre "became a lifeline for many" (see Hinks 1993: 14) but some people were wary of accessing it. Social workers asserted control over the space and the nature of activities. Sheila and Peter noted some survivors did not completely trust their motives and feared stigmatization or further condemnation (see also Newburn 1993). The Centre disbanded after two years, leaving individuals and volunteer campaign groups (Hillsborough Justice 
Campaign (HJC) and the Hillsborough Family Support Group (HFSG)) to cover professional counselling services. Survivors felt abandoned by the lack of longer term provision, and they came to rely on "their own survival skills" (Sheila). Nick explained: "an awful lot of people have slipped through the net and ... it's much harder for them to go and ask for help" years after the disaster. Similar to other victims of state crime, navigating the various social struggles that accompany survival in the long-term aftermath can be "crippling" (Stanley 2005: 583).

Finally, and fifth, survival was continually stymied by the persistent expectations from mainstream media, public officials and wider society that those affected should "get over" Hillsborough (see also Knight 2017). Paul articulated this situation:

I think the moving on argument is hard for us to understand. It's very easy for the outside world to say "move on". Unless you're part of it, unless you feel a massive burning sense of injustice, it's hard to move on.

Sometimes, officials and media have constructed this inability or lack of desire to "just forget" as an indicator of problematic attitudes or behaviours (Eyre 2006; Newburn 1993), of survivors' deficits and their inability to overcome trauma in a timely way. Many influential public figures have reflected these attitudes, from UKIP donor, Arron Banks, who commented that he was "sick to death" of hearing about Hillsborough (Elgot 2017) to Sir Oliver Popplewell — one of England's most distinguished High Court judges - who publicly criticized bereaved family members for not moving on and harbouring "conspiracy theories" (Holehouse 2011). Now PM Boris Johnson even identified Liverpool as a city of self-pity; he argued Liverpudlians "see themselves whenever possible as victims" due to their "flawed psychological state" (The Spectator 2004: para. 3).

Despite these vilifying discourses, Nick observed that survivors "are getting on with their lives and remarkably so actually considering what they've gone through." Survivors have demonstrated deep levels of resiliency, yet their survival pathways have been continually stymied by state protective narratives and unjust institutional (media and legal) activities that have created barriers to survival. Stigmatizing misrepresentations as well as practices of non-recognition have been strategically engaged to devalue and undermine experiences of victimization and long-term trauma (Stanley 2015). In this context, survivors were supposed to just get over it.

These experiences have brought a heavy toll for many survivors. Families have split up, children have grown up knowing nothing but the fight for Hillsborough, people lost friends and lives. While survivors have been affected by "pretty high divorce rate, high separation rates" (Paul), they also experienced damage to wider relationships. For example, people lost their jobs and so lost contact with work-based 
networks, and they saw their friend circle diminish (see Tempany 2009). Some said that Hillsborough was all they could talk about at times, and that was very draining for others (see Hinks 1993). At the same time, some never spoke to family or friends about Hillsborough. They feared being blamed, but they also did not want to burden those closest to them with their pain or anger. They often felt deeply isolated. While they have survived Hillsborough, they have continued to experience hurt and trauma.

\section{Moving Beyond State-Led Disasters}

Survival is a highly complicated endeavour, especially when individuals have to navigate multiple victimizations. As noted above, there are contradictory states of survival whereby survivors might engage in positive coping strategies towards one element of victimization, while struggling to cope in other aspects. As Peter reflected: "Survival is a varied experience, it comes and goes in different shapes and forms .... it's an ongoing dynamic ... so it doesn't stop." Even in the best conditions, survival is a constant struggle and highly dependent on others. As survivor Martin Hinks (1993: 20) explains, "to get to 'the end of the storm' requires much soul searching and pain to be worked through. This cannot be accomplished alone."

In the wake of state-led disaster and the subsequent misrepresentations and mistreatments, survivors spoke of being mentally strong and having "inner reserves of strength" (Dan) such that "they weren't ever gonna give up" (Tony). Essentially, they described their resiliency or their ability to endure. Three overarching approaches have emerged to strengthen survival in these conditions: (i) opening up; (ii) becoming actively involved in campaigns and formal legal processes; and (iii) building social networks and political solidarities. Taken together, these actions illustrate that survival — and being resilient — significantly depends on positive relationships and collective actions.

\section{Opening Up}

Survivors tried to protect themselves from stigmatizing associations. One approach was to distance themselves from Hillsborough. Some threw themselves into work, and rarely told people they were actually involved - survivor Richie Greaves said he "couldn't even bear hearing the word Hillsborough" (Conn 2017: para. 10). Others travelled the globe in attempts to find solace (see Sampson 2016). As Adrian explained:

about four years afterwards ... I wanted to literally get as far away in the world as I could and that's why I went to New Zealand, and for me that was the first time I actually found any peace in my head. 
Such distancing could not always be maintained, and some got to the point where they needed to open up and share their experiences (Bracken 2009). For many people, it has taken years to be able to speak about Hillsborough (Newburn 1993). Even now, Paul spoke about the continual pain, "you know clearly its 27 years later it's still difficult to talk about." Those who received professional help to open up said it was the best survival decision they made. Nick spoke of his counselling experiences:

I don't sugar-coat it, it's hard but I quote it as the best thing I ever did. Before I had it I was in a low place you know, I was on the phone to the Samaritans a couple of times, so I daren't think what might have happened if I hadn't got help.

Yet, given their negative experiences with official services, and the ways official agencies shut down recognition of their victimization, many survivors sidestepped formal support. They focused on speaking to others - especially survivors and bereaved - who might understand their experiences, and who were more likely to understand the cover-up and its implications. Many (including Nick and Tim) have reached out to help and support others dealing with trauma. One survivor, Stevie Dooling, became a go-to person during football matches: "people all over the country were coming up and talking to me and it got really heavy doing that. It was every single match 'go and see him, he'll counsel you"' (HJC n.d.). Opening up, for him and many others, was a vital but difficult step in acknowledging and moving beyond the painful harms of Hillsborough.

\section{Getting Involved in Campaigns and Actions}

Survivors also emphasized the importance of being politically active (see Eyre 2006). Their grassroots campaigning created meaningful political change, but it also improved chances to receive support and human connection. Being active in campaigns and legal cases helped to satisfy their need to do something but it also comforted them by breaking isolation (Dan). Amid wider public stigmatization, they drew strength from their solidarity and shared identity with others, and were able to create a community out of that "othered" population.

Participants spoke with warmth about the charity fundraisers, that brought so many people together. "There was always something going on ... to get some money to carry on fighting against the government" (Tony). Despite the seriousness, people had fun and enjoyed the camaraderie, whilst raising money they desperately needed (see also Bowman 2012). As people became more actively involved in campaigning, they often took on other roles: becoming researchers, public figureheads for the fight for justice or informal counsellors to other survivors. They established beneficial spaces for support-not least through the work of the HJC and the HFSG. 
While not all survivors have been actively involved in campaigns, most supported them. For example, every interviewee boycotted The Sun-this remains one of the most successful and sustained boycotts (Sledge 2018). Thousands boycotted a major game in May 1989 as it was held at Hillsborough and sponsored by The Sun. ${ }^{10}$ Survivors gained strength from seeing the HJC stickers around Liverpool and elsewhere. They admired the justice banners at football grounds, and participated in the mass chants for justice. These solidarity actions brought fundamental shifts, as Steve reflected:

It's quite easy for a government to deal with the fact that 96 families will go down to Number 10 Downing Street banging on the door saying "Can we have justice for the 96?". But when every other Saturday at Anfield 50,000 are chanting "Justice for the 96" and they don't stop, well then someone listens. And, that's exactly what happened when Andy Burnham got up on the 20th anniversary, people started chanting and that was the changing point and again it was that community base, that group of people, that forced the hand of the government.

After being moved by the crowd, then Labour MP Andy Burnham filed a Freedom of Information request to release all privately held documents relating to the disaster. This initiated other events, including the HIP Report, the 2016 IV, the quashing of previous verdicts and the unequivocal clearing of blame for fans. These processes positively changed survival trajectories.

This is not to say, of course, that official processes have not been without problems. For example, trying to follow and support the recent inquests brought many burdens. Steve, who attended the proceedings, noted it was:

the unseen things you gave up: time with your family, time at home ... I virtually gave up work so you couldn't claim benefits, so you were living off your life savings and that's what l've done for the last three years. But none of that mattered, the fight mattered.

There was a common internal conflict expressed between doing what they personally needed and doing what they felt was right, understanding that those choices often stood in direct opposition. For instance, it was not easy to maintain a public face for the Hillsborough truth and justice campaign, or to mark anniversaries in public settings. Steve recounted: "to keep continuing, having to show your soul, it takes something out of you every time."

Further, every participant expressed disappointment in how the fresh inquests were carried out. They spoke about the revictimizing, adversarial stance of authorities who "regurgitate[d] the old lies" (Nick) and denials (see also Tempany 2016). 
They identified survivors and prematurely aged family members who were retraumatized, and the emotional toll it took on people because "all of this [knowledge] was already known" (Dan). Further, while the survivors gained some recognition for their heroic acts of rescue on the day of disaster and were legally cleared of any causation in the disaster, the Coroners Court could not provide official redress. Similarly, recent legal cases that have failed to provide any resolution or substantive accountability (and also created space for one QC to further blame fans ${ }^{11}$ ) have exacerbated victims/survivors' pains. There is immense anger, disgust and disappointment at these outcomes. For one mother, Brenda Fox, "it's like going back to the start" (BBC News 2021).

The long-term impacts of being misrepresented, blamed and unsupported have never been rectified in any meaningful or practical way. Despite these issues, survivors stressed the importance of the 2016 IV and identified that well-functioning proceedings can bring significant positive impacts to survivors' quality of life. Undertaken with proper consideration for victims/survivors and the bereaved, official mechanisms can provide a source of resolution, and a sense of survivor solidarity among those victimized.

\section{Building Solidarities}

The third significant survival factor related to how survivors built networks with those who could understand them, or work towards their cause. Dean Harris stated that the main thing that has shaped his survival has been "the solidarity of being with people, fighting one cause, coming together, staying together" (Harris 2016: $6 \mathrm{mins} 11 \mathrm{secs}$ ). As shown above, survivors often supported each other. Interviewees reflected on the instant bond they felt when they met other survivors: "If you've shared an experience like that you become fast friends" (Tim). Peter recounted:

Besides family for me, it was other survivors, they were the greatest help... to listen to other survivors and hear about the struggles that they went through. It was swap and share, you tell me what you're going through and l'll tell you what I'm going through. And in the mix each one of us will find a benefit or a use for that and that was massive.

In the absence of adequate professional help, some survivors dedicated years of their life to supporting others, "going into their homes ... spending hours and hours during the night on phones with people" (Steve). Tony explained, "like a community you get involved with people ... you could be speaking with someone you mightn't really know till 4 o'clock in the morning." Beyond these personal encounters, communities of support emerged online-also helping reconnect survivors with the individuals who saved them (BBC News 2016). Social media 
connections reduced feelings of isolation (especially for those living outside Liverpool), and often provided a focal point of resistance to wider misinformation on Hillsborough.

Alongside, survivors warmly acknowledged the professionals who worked to assist - academics like Phil Scraton, or solicitors that worked pro-bono, or MPs who vigorously supported the campaign. They discussed the many unsung heroes, including police constables and ambulance drivers, who challenged the establishment version of events, despite detrimental impacts on their careers and wellbeing (Tempany 2009). They detailed how other victimized communities - such as members of the Birmingham 6, the Guildford 4 or bereaved family members of people who died in police custody - gave them encouragement, practical advice on sustained campaigning and a sense of strength, especially during times when they felt like the tide was against them (also see Sampson 2016). And they acknowledged the countless others - often "ordinary working class" people (Sheila) — who worked, seeking no recognition, in solidarity with the Hillsborough campaign. Some of these people had no direct link to Hillsborough but they gave up many years to support the justice campaign. One such example, raised by Steve and Sheila, was "Gerry'12 the old guy in the [HJC] shop. Day in day out, [he] talked to people, helped people, saved lives" (Sheila).

All of this points to a key issue: that survival depends on collective responses, and the actions of communities of solidarity to listen, progress campaigns, research and publish, memorialize, advocate, provide support and stand alongside survivors. Survival and well-being requires positive creation, including the making of new relationships and worlds, that goes beyond the state and official processes. In the wake of disaster, resiliency (that is often framed as an individual act) can never be a sole endeavour.

\section{What Do Survivors Need?}

There are, as the discussions above illustrate, diverse pathways to survival. The continuum of survival means that individuals are continually negotiating their state of survival, and that this is dependent on external factors including the actions of others:

l'd say each survivor needs their own space for it... [we] need to be sensitive to what the survivors need to have and that's multifaceted . . . I don't think there is a single formula for that, because we're all such different beings aren't we? (Peter)

Survivors' needs cannot be generalized, especially when their many layers of experience are complicated by state denials, cover-ups and vilification. Yet, as with other victims of state crime, Hillsborough survivors are caught in a double 
bind as they require state agencies (their offenders) to take positive action- to provide official recognition, criminal justice, professional and relational support, and so on.

Despite the problems of official proceedings, noted above, every participant thought that the recognition provided through the 2016 IV and HIP Report brought immediate positive differences to their lives. These processes rectified misinformation and misinterpretations of Hillsborough, and legally registered the known realities. They recognized the individuals, agencies and institutions that were responsible for the disaster and their damaging responses to victims/survivors. Survivors needed this legitimate stamp to gain wider public support. Indeed, they experienced a groundswell of support post-HIP, as Adrian explained:

The panel coming out in 2012 was massive, because we won the argument then, that was the end of the debate and now the Inquest Verdict that is life changing, because it's a historical fact now it can never be overturned.

Similarly, Paul observed that, after the Inquest verdict, many people who had "aged with a weight on their shoulders" had changed: "S . . is smiling, people are smiling, people that I've never seen smile are laughing and joking ... they've been to hell and back really" (Paul). Some observed that the vindicatory power of these official processes was such that they did not have to worry about others who had been at risk of suicide. Adrian noted: "people think that ... truth, justice are just a legal instrument, it's not, it has a massive impact on people's mental health." Recognition is vital to survival. Yet, as Dan explained, these shifts are bitter-sweet, particularly as people will probably feel "a never-ending anger that many of their friends and fellow survivors have died before seeing it." Moreover, they can be temporary measures, especially when later official responses reiterate injustice.

In line with other victims/survivors of state crime, Hillsborough survivors also noted that socio-cultural recognition was not enough. They spoke passionately about criminal justice, and the need for those responsible for the disaster and coverup to face "the full force of the law" (Paul). Many interviewees brought up the introduction of a Hillsborough Law "that would force them [authorities] to truthfully co-operate with inquiries and inquests" (Peter). This Law might restore public faith and "credibility" in state institutions (Dan) while creating protections against future miscarriages of justice. More broadly, survivors frequently advocated for Hillsborough to be taught in schools as part of the national curriculum. They were concerned with the legacy of Hillsborough, the lessons that need to be learnt and the systems that need to be amended. As survivor Damian Kavanagh articulated, any teaching would ensure that "The suffering that has been endured by the bereaved, by the survivors" will be "recorded in history" (Sampson 2016: 327). 
Beyond the social and institutional actions necessary for positive survival journeys, everyone reflected on the importance of continuing specialized support. They spoke about establishing a Survivors Association, a permanent support centre in Liverpool, and an online network for anyone suffering trauma. ${ }^{13}$ They remain proactive in fulfilling their own survival needs, as well as those of others. More recent actions have allowed politically oriented survivors to also think about more "normal" futures. They expressed their need to continue onto the next life stage without everything being in relation to Hillsborough. As Paul put it: "I'd like to go back to having conversations other than Hillsborough." At the same time, survivors still required a space to be able to "be", with others who understand exactly what they've suffered over decades. While Hillsborough would "always be there" (Paul), especially given ongoing injustices, they wanted to now create new spaces.

\section{Conclusion: Surviving State-Led Disaster}

Writing 20 years after he experienced the Hillsborough disaster, Tempany (2009: para. 21) acknowledged that it is obvious "that the very act of surviving a major tragedy changes people's lives and personalities" but what is less obvious is that survivors constantly navigate and negotiate their own survival. This means that there cannot be an assumed set of prescribed processes that are automatically enacted as a response. While some requirements for survival are common (e.g. official recognition, professional and personal support, and accurate representations are all necessary), responses to survivors must be flexible and adaptable as their journeys progress and their needs change.

A continuum perspective is necessary to acknowledge the multi-dimensional elements of survival, and to expose overlooked forms of victimization (Kelly 1988; Profitt 1996). This allows us to understand that individuals can be resilient and endure adversity, but they can simultaneously feel traumatized and struggle to cope (Profitt 1996). At different points in time, people can revert from surviving to struggling and vice versa. In this respect, surviving does not mean the end of victimization or the attainment of "closure." Rather, victim/survivor identities constantly fluctuate, depending on contextual factors. This is all the more important to recognize when state crime survivors are marginalized and revictimized by powerful agencies and actors (Davis 2012; Scraton 2016). These survivors have to navigate their own survival trajectories, but also the continuing disadvantageous and unjust responses to them.

In many ways, the term survivor does not reflect the diverse complexities involved in surviving. Many survivors have experienced a roller-coaster reality, and social expectations of a linear survival trajectory create unhelpful judgements and even pressure survivors to not be seen as failing at survival (Kelly 1988; Newburn 1993). Along with this, there is a "hierarchy of worthiness" where some 
survivors feel they are undeserving as they perceive others to be "much worse off" (Newburn 1993: 51). Such problems are exacerbated when survivors endure extensive victim-blaming while officials enjoy impunity.

The deflection of official responsibility or accountability is enabled through the neo-liberal model of resilience, which encourages individuals to support their own survival in the aftermath of disasters (Manyena et al. 2011; Shaw 2012). Those who stoically cope well (Eyre 2006) may assist themselves but they may also cover over the harms and those responsible for them. Further, wider expectations of self-help and resiliency can prevent survival, as they make survivors feel less comfortable or less worthy to disclose struggles or ask for help. And, beyond this, survivors have to display the right kind of resiliency. Those who react or express their trauma in ways that are not silent, or who challenge official responses through campaigns, can be perceived by officials and media as problematic or vilified as a threat.

The frames of resiliency that dominate discussions on survival following major disasters are undoubtedly individualistic. Yet, as this research repeatedly illustrates, survival is not an individualized pursuit. Rather, it depends on collectives, and requires supportive actions from various individuals and groups, including state agencies. In this respect, survival is a deeply political and social process. These findings indicate that an effective response to survivors cannot be bureaucratized, stemming from a neo-liberal individualized focus, as this prevents empathetic supports and fails to acknowledge the wide-ranging experiences of victimization (Davis 2012; Eyre 2006). In reality, survivors need othersincluding academics, professionals, community members, lawyers, media workersto commit to a humanitarian response that responds to what they need, at specific points, during their survival journey. It entails people standing alongside survivors and working in their interests. This requires varied resistance actions-from challenging the culture of denial and the normalization of state collusion, corruption or cover-up in the wake of disasters to more quiet, mundane acts that assist survivors on an everyday, personal level. Alongside a focus on individual needs, those engaged in support have to engage with the wider societal, political or economic structures that contribute to disasters, or that prevent survival trajectories. After all, without making these connections between personal troubles and social issues, the transformation of structures and institutional processes that underpin state-led victimization will be much harder to achieve.

\section{Notes}

1. On 27 July 2021, Andrew Devine died as a result of serious injuries sustained thirty-two years before at Hillsborough. The following day, Coroner Andre Rebello concluded that he was unlawfully killed - this officially recorded Andrew Devine as the 97th victim of Hillsborough. Through this article, discussions revolve around "the 96", reflecting the long-standing official recording of 
those killed. There have been many other people whose lives have been cut very short as a result of Hillsborough. The psychological trauma of the event, as well as continuing injustices and limited supports, have led to countless people having untimely deaths, from long-term ill-health as well as suicides. As Evans (2021) reports: "At funerals there is a common mantra: 'They were never the same after Hillsborough'. None of the survivors were."

2. The events at Hillsborough are commonly reported as a "disaster." This should not be regarded as a "natural" tragedy. Many disasters and their impacts often result from human actions or inactions.

3. The term Hillsborough is used to refer to the specific event, but also to longer term processes (such as inquests, inquiries, etc.).

4. The case against Ch Supt Donald Denton, DCI Alan Foster and Peter Metcalf was stopped after the judge ruled that their alteration of police statements was undertaken for Lord Justice Taylor's public inquiry into the disaster. It was determined that this inquiry was not a statutory inquiry at which evidence is given on oath. As a result, charges of perverting the course of justice could not stand.

5. While there were direct survivors - those whose lives were in danger, in pens three and four, on the day - there are many thousands who "survived the experience" of Hillsborough (Paul), including witnesses, rescuers, LFC fans, the entire city of Liverpool, campaigners, and generations of families and friends. These people have experienced diverse trajectories of survival.

6. This article was completed in 2018. However, it has been held from publication for over three years, following direction to refrain from commentary that could prejudice legal proceedings.

7. We extend our deep appreciation to all interviewees and others who have supported this research.

8. There are several sites through which survivors express their concerns, experiences and difficulties. See articles on LFChistory.net, The Echo Online, Contrast and Hope for Hillsborough Justice, among others.

9. Anne's 15-year-old son Kevin was killed in pen three at Hillsborough. Anne was a member of the HJC, she formed the Hope for Hillsborough charity and dedicated her life to challenging the original inquest verdicts and the " $3.15 \mathrm{pm}$ cut-off" decision on all evidence. She presented the case to four Attorney Generals and took it to the European Court of Human Rights. Anne passed away on 18 April 2013.

10. Only $14 \%$ of tickets were taken up for the 8 May 1989 match between Sheffield Wednesday Football Club and LFC (http://www.contrast.org/hillsborough/boycott.shtm).

11. Despite the vindication from the HIP Report and 2016 IV, Jonathan Goldberg QC claimed that Liverpool supporters' behaviour had been "perfectly appalling . . . causing a riot" (Conn, 2021).

12. Gerry McIver passed away in August 2016.

13. Recently, there has been the development of a "Survivors Support Alliance" (https://www.hsa-us. co.uk/).

\section{References}

Alatartseva, E. and Barysheva, G. (2015) "Well-Being", Procedia: Social and Behavioral Sciences, 166(7): 36-42.

Arnold, H. (1989) “The Truth", The Sun, 19 April: P1.

BBC News (2016) “Hillsborough: Man Reunited with 'Hero' Who Saved Him”, 20 May. Available online at: www.bbc.com/news/uk-wales-36340867 (accessed 22 May 2016).

BBC News (2021) "Hillsborough Trial: Men Acquitted as Judge Rules No Case to Answer", 26 May. Available online at: https://www.bbc.com/news/uk-england-merseyside-57172900 (accessed 23 October 2021). 
Bracken, M. (2009) “This is my Hillsborough", The Guardian, 14 April. Available online at: https:// www.theguardian.com/lifeandstyle/2009/apr/14/hillsborough-post-traumatic-stress-disorder (accessed 27 July 2021).

Bowman, J. (2012) “The Hillsborough Justice Band and a Cause Worth Fighting For", Getintothis, 20 September. Available online at: www.getintothis.co.uk/2012/09/the_hillsborough_justice_band/ (accessed 25 September 2020).

Christie, N. (1986) "The Ideal Victim", in E.A. Fattah, ed., From Crime Policy to Victim Policy: Reorientating the Justice System. London: Macmillan.

Conn, D. (2017) "Hillsborough Disaster: Survivors Seek Justice for Alleged Police Cover-Up", The Guardian, 2 January. Available online at: www.theguardian.com/football/2017/jan/02/hillsborough-disaster-survivors-seek-justice-for-alleged-police-cover-up (accessed 5 January 2017).

Conn, D. (2021) "Hillsborough Families Attack 'Ludicrous' Acquittals of Police", The Guardian, 26 May. Available online at: www.theguardian.com/football/2021/may/26/hillsborough-trial-offormer-south-yorkshire-police-officers-collapses (accessed 26 May 2021).

Daly, K. (2017) “Sexual Violence and Victim's Justice Interest”, in E. Zinsstag and M. Keenan, eds., Restorative Responses to Sexual Violence: Legal, Social and Therapeutic Dimensions. Abingdon, Oxon: Routledge.

Davis, H. (2012) "Contextual Challenges for Crisis Support in the Immediate Aftermath of Major Incidents in the UK", British Journal of Social Work, 43(3): 504-21.

Elgot, J. (2017) “Arron Banks Defends 'Sick of Hearing about Hillsborough' Remarks”, The Guardian, 22 February. Available online at: www.theguardian.com/politics/2017/feb/22/arronbanks-defends-sick-of-hearing-about-hillsborough-remarks-ukip-donor (accessed 27 July 2021).

Evans, T. (2021) “Andrew Devine is Far from the 97th Victim of Hillsborough", The Independent, 30 July. Available online at: www.independent.co.uk/sport/football/andrew-devine-hillsboroughdisaster-liverpool-b1893143.html (accessed 31 July 2021).

Eyre, A. (2006) Literature and Best Practice Review and Assessment: Identifying People's Needs in Major Emergencies and Best Practice in Humanitarian Response. London: Department for Culture, Media and Sport.

Faust, K.L. and Kauzlarich, D. (2008) "Hurricane Katrina Victimization as a State Crime of Omission", Critical Criminology, 16(2): 85-103.

Grbich, C. (2013) Qualitative Data Analysis. 2nd ed. London: Sage Publications.

Green, P. (2005) "Disaster by Design: Corruption, Construction and Catastrophe", British Journal of Criminology, 45(4): 528-46.

Green, P. (2008) "Women and Natural Disasters: State Crime and Discourses in Vulnerability", in M. Cain and A. Howe, eds., Women, Crime and Social Harm. Oxford: Hart Publishing.

Harris, D. (2016) "LFC TV: Hillsborough Survivors' Stories". Available online at: www.liverpoolfc. com/news/announcements/218346-hillsborough-survivors-stories (accessed 27 July 2021).

Herman, J. (2003) “The Mental Health of Crime Victims: Impact of Legal Intervention”, Journal of Traumatic Stress, 16(2): 159-66.

Herman, J. (2005) “Justice from the Victim's Perspective”, Violence Against Women, 11(5): 571-602.

Hillsborough Independent Panel (2012) Hillsborough: The Report of the Hillsborough Independent Panel, House of Commons. HC581. London: The Stationery Office.

Hillsborough Justice Campaign (n.d.) Hillsborough Justice Campaign: Survivors. Available online at: www.contrast.org/hillsborough/history/stevie.shtm (accessed 27 July 2021).

Hinks, M. (1993) “'We Went to See Liverpool Get to Wembley’: The Experience of a Hillsborough Survivor", in T. Newburn, ed., Working with Disaster: Social Welfare Interventions During and After Tragedy. Harlow: Longman. 
Holehouse, M. (2011) "Hillsborough Disaster: Sir Oliver Popplewell Outrages Campaigners with Comments", Daily Telegraph, 19 October. Available online at: www.telegraph.co.uk/sport/ football/teams/liverpool/8835870/Hillsborough-disaster-Sir-Oliver-Popplewell-outragescampaigners-with-comments.html (accessed 27 July 2021).

Hooks, J.P. and Miller, T.B. (2006) "The Continuing Storm: How Disaster Recovery Excludes Those Most in Need", California Western Law Review, 43(1): 21-74.

Kelly, L. (1988) Surviving Sexual Violence. Cambridge: Polity Press.

Knight, I. (2017) "Not Guilty! And the Guilt that Never Goes Away", Echo Online, 15 April. Available online at: www.liverpoolecho.co.uk/news/liverpool-news/guilt-never-leaves-hillsborough-survivors-12889732 (accessed 27 July 2021).

Leichenko, R., McDermott, M. and Bezborodko, E. (2015) "Barriers, Limits and Limitations of Resilience", Journal of Extreme Events, 2(1): 1-27.

LFC History (2019) Articles: Hillsborough Survivors. Available online at: https://www.lfchistory.net/ articles/article/2890 (accessed 27 July 2021).

Lundy, P. (2016) Historical Institutional Abuse: What Survivors Want from Redress. Belfast: University of Ulster. Available online at: https://core.ac.uk/reader/287020757 (accessed 23 October 2021).

Lundy, P. and Mahoney, K. (2018) "Representing Survivors: A Critical Analysis of Recommendations to Resolve Northern Ireland's Historical Child Abuse Claims", Annual Review of Interdisciplinary Justice Research, Vol. 7: 258-91.

Manyena, S.B., O’Brian, G., O’Keefe, P. and Rose, J. (2011) "Disaster Resilience: A Bounce Back or Bounce Forward Ability?", Local Environment: The International Journal of Justice and Sustainability, 16(5): 417-24.

McGreavy, B. (2015) "Resilience as Discourse", Environmental Communication: A Journal of Nature and Culture, 10(1): 104-21.

Newburn, T. (1993) Making a Difference? Social Work After Hillsborough. London: National Institute for Social Work.

Olson, R.S. (2000) “Toward a Politics of Disaster: Losses, Values, Agendas, and Blame”, International Journal of Mass Emergencies and Disasters, 18(2): 265-87.

Orth, U. (2002) "Secondary Victimization of Crime Victims by Criminal Proceedings", Social Justice Research, Vol. 15: 313-25.

Press Association (2016) "How the Hillsborough Inquest Jury Ruled on the 14 Key Questions", The Guardian, 26 April. Available online at: https://www.theguardian.com/uk-news/2016/apr/26/14questions-the-hillsborough-jury-must-answer (accessed 26 April 2016).

Prilleltensky, I. (2008) “The Role of Power in Wellness, Oppression, and Liberation: The Promise of Psychopolitical Validity", Journal of Community Psychology, 36(2): 116-36.

Prilleltensky, I. and Prilleltensky, O. (2005) "Beyond Resilience: Blending Wellness and Liberation in the Helping Professions", in M. Ungar, ed., Handbook for Working with Children and Youth: Pathways to Resilience across Cultures and Contexts. Thousand Oaks, CA: Sage Publications.

Profitt, N.J. (1996) “'Battered Women' as 'Victims' and 'Survivors': Creating Space for Resistance”, Canadian Social Work Review, 13(1): 23-38.

Sampson, K. (2016) Hillsborough Voices. London: Ebury Press.

Scraton, P. (1999) "Policing with Contempt: The Degrading of Truth and Denial of Justice in the Aftermath of the Hillsborough Disaster", Journal of Law and Society, 26(3): 273-97.

Scraton, P. (2013) "The Legacy of Hillsborough: Liberating Truth, Challenging Power", Race and Class, 55(2): 1-27.

Scraton, P. (2016) Hillsborough: The Truth. Edinburgh: Mainstream Publishing Co. 
Scraton, P., Coleman, S. and Jemphrey, A. (1990) Hillsborough and After: The Liverpool Experience. First Report. Ormskirk: Edge Hill.

Scraton, P., Jemphrey, A. and Coleman, S. (1995) No Last Rights: The Denial of Justice and the Promotion of Myth in the Aftermath of the Hillsborough Disaster. Liverpool: Liverpool City Council.

Shaw, K. (2012) “The Rise of the Resilient Local Authority?", Local Government Studies, 38(3): 281-300.

Sledge, B. (2018) “Eclipse of The Sun: Liverpool's 30-Year Boycott is Still Going Strong”, The Overtake, 19 July. Available online at: https://theovertake.com/ protest/liverpool-vs-the-sun/?fbclid=iwar2ydrqxu5 psbbkgxgmenmwez4vvzfyiala3f7nupyxuv6vefykijrajus (accessed 23 July 2018).

Smith, G. and Heke, S. (2010) "From Report to Court: Psychology, Trauma and the Law", workshop presented at the UK Psychological Trauma Society 3rd Annual Conference, January. Available online at: www.yumpu.com/en/document/view/43055392/from-report-to-court-psychology-trauma-and-thelaw-ukpts (accessed 27 July 2021).

Spring, U.O. (2011) "Social Vulnerability, Discrimination, and Resilience-Building in Disaster Risk Reduction”, in H.G. Brauch, U.O. Spring, C. Mesjasz, J. Grin, P. Kameri-Mbote, B. Chourou. P. Dunay and J. Birkmann, eds., Coping with Global Environmental Change, Disasters and Security. Berlin: Springer.

Stanley, E. (2015) "Responding to State Institutional Violence", British Journal of Criminology, 55(6): $1149-67$.

Tempany, A. (2009) "Twenty Years After Britain's Worst Stadium Disaster, Adrian Tempany and Five Other Survivors Describe the Impact Hillsborough has Had on their Lives", The Guardian, 15 March. Available online at: www.theguardian.com/football $/ 2009 / \mathrm{mar} / 15 /$ hillsborough-disastersurvivors (accessed 19 May 2019).

Tempany, A. (2016) And the Sun Shines Now: How Hillsborough and the Premier League Changed Britain. London: Faber \& Faber.

The Spectator (2004) "Bigley's Fate: We have Lost our Sense of Proportion about what Constitutes a Tragedy", 16 October. Available online at: www.spectator.co.uk/article/bigley-s-fate (accessed 27 July 2021).

Thompson, M. (2017) "My Brother Died at Hillsborough. At Last, After 28 Years, I Can Sleep Soundly", The Guardian, 2 July. Available online at: www.theguardian.com/football/2017/jul/01/ hillsborough-football-disaster-tragedy-inquiry-liverpool (accessed 2 July 2017).

Tombs, S. and Whyte, D. (2007) Safety Crimes. Cullompton: Willan.

Urbatsch, R. (2016) "Judgement Days: Moral Attitudes in the Wake of Local Disasters", Disasters, 40(1), 26-44.

Verchick, R.R.M. (2012) “Disaster Justice: The Geography of Human Capability”, Duke Environmental Law and Policy Forum, 23(1): 23-71.

Walklate, S. (2007) Imagining the Victim of Crime. Maidenhead: Open University Press.

Williams, S. and Kay, D. (2013) With Hope in her Heart: Anne Williams. Liverpool: Trinity Mirror Sport Media. 